\title{
Distribution and Accumulation of Major and Trace Elements in Gypsum Samples from Lignite Combustion Power Plant
}

\author{
Majda Pavlin1,2, Radojko Jaćimović1,2, Andrej Stergaršek ${ }^{3}$, Peter Frkal ${ }^{4}$, Maja Koblar1,5, \\ Milena Horvat ${ }^{1,2^{*}}$ \\ ${ }^{1}$ Jožef Stefan International Postgraduate School, Ljubljana, Slovenia \\ ${ }^{2}$ Department of Environmental Sciences, Jožef Stefan Institute, Ljubljana, Slovenia \\ ${ }^{3}$ KEMEK d.o.o., Ljubljana, Slovenia \\ ${ }^{4}$ Department of Inorganic Chemistry and Technology, Jožef Stefan Institute, Ljubljana, Slovenia \\ ${ }^{5}$ Center for Electron Microscopy and Microanalysis, Jožef Stefan Institute, Ljubljana, Slovenia \\ Email: *milena.horvat@ijs.si
}

How to cite this paper: Pavlin, M., Jaćimović, R., Stergaršek, A., Frkal, P., Koblar, M. and Horvat, M. (2018) Distribution and Accumulation of Major and Trace Elements in Gypsum Samples from Lignite Combustion Power Plant. American Journal of Analytical Chemistry, 9, 602-621. https://doi.org/10.4236/ajac.2018.912044

Received: October 24, 2018

Accepted: December 15, 2018

Published: December 18, 2018

Copyright (c) 2018 by authors and Scientific Research Publishing Inc. This work is licensed under the Creative Commons Attribution International License (CC BY 4.0).

http://creativecommons.org/licenses/by/4.0/

\begin{abstract}
Flue gas containing volatile elements, fine fly ash particulates not retained by particle control devices, and limestone are the most important sources of trace and major elements (TMEs) in wet flue gas desulphurization (WFGD) gypsum. In this study, samples of gypsum slurry were separated into fine and coarse fractions. Multi-elemental analysis of 45 elements in the different size fractions of gypsum, slurry waters and lignite were performed by $k_{0}$-INAA ( $k_{0}$-instrumental neutron activation analyses). The study found that the volatile elements ( $\mathrm{Hg}$, Se and halogens) in the flue gas accumulate in the fine fractions of gypsum. Moreover, the concentrations of most TMEs are considerably higher in the fine fractions compared to the coarse fractions. The exceptions are $\mathrm{Ca}$ and $\mathrm{Sr}$ that primarily originate from the limestone. Variations of TMEs in the finer fractions are dependent on the presence of $\mathrm{CaSO}_{4} \cdot 2 \mathrm{H}_{2} \mathrm{O}$ that is the main constituent of the coarse fraction. Consequently, the content of TMEs in the fine fraction is highly dependent on the efficiency of separating the fine fraction from the coarse fraction. Separation of the finer fraction, representing about $10 \%$ of the total gypsum, offers the possibility to remove effectively TMEs from WFGD slurry.
\end{abstract}

\section{Keywords}

Trace and Major Elements, Wet Flue Gas Desulphurization Gypsum, Particle Size Fractions, Mercury and Selenium, Sample Preparation 


\section{Introduction}

Coal combustion is the major source of airborne $\mathrm{Hg}$, Mo and $\mathrm{Se}$, and is a significant source of $\mathrm{As}, \mathrm{Cr}, \mathrm{Mn}, \mathrm{Sb}$ and $\mathrm{Tl}$ [1]. Not only trace elements, but also $\mathrm{SO}_{2}$, $\mathrm{NO}_{x}, \mathrm{CO}_{2}, \mathrm{~N}_{2} \mathrm{O}$, particulate matter and various gases are released into the environment by coal burning [2]. In general, the elements present in coal occur over a wide concentration range that varies according to the geochemical evolution of the coal deposits [3] [4] [5] [6] [7]. Based on their concentrations, chemical elements in coal are classified into three groups [8] with further division of trace elements according to their volatility [8] [9] [10] [11]. The volatility of trace elements is the result of several factors: affinity to other elements, their physical properties, chemical reactions and transformations [11], but it also depends on the combustion setup (e.g. combustion temperature, time of exposure, ash generation) [3] [4] [8] [11] [12]. Volatile elements are preferentially concentrated on the smallest particles due to condensation [11] whereas the non-volatile ones deposit on the largest ash particles [13]. As a result, the finest fly ash particles contain larger amounts of (trace) elements, due to their greater surface to volume ratio [3] [8] [9] [10] [11] [14].

Important sources of trace and major elements (TMEs) in the gypsum slurry are attributed to the flue gas with fly ash particles [8] [9] [10] [11] [15] [16] not retained in the particle control devices [17] [18] [19] [20] [21] and limestone added to the wet flue gas desulphurisation (WFGD) system [22]. Small particles pass through the electrostatic precipitator (ESP), reach the WFGD device and are retained there due to adsorption, co-precipitation or other chemical reactions [23] [24]. Although trace elements are greatly accumulated in gypsum [15], a smaller amount is emitted to the atmosphere through the stack gas [13] [20]. The control of emissions in the gaseous phase and small particulates is very important. In power plants equipped with WFGD systems, both emissions are reduced [11].

Gypsum as a by-product of the WFGD process is important in terms of its disposal in landfills and/or for its further production and use [25] [26] [27]. Typically, it is mostly composed of $\mathrm{CaSO}_{4} \cdot 2 \mathrm{H}_{2} \mathrm{O}$ [27] [28] and minor amounts of silica, alumina, iron oxide, and other minerals [27] [29]. Many pollutants in a gaseous form and/or as particulate matter are partitioned into solid and water streams of gypsum slurry. Under operational conditions of water recirculation from gypsum slurry, some inorganic trace pollutants are enriched in recirculated water streams by dissolution. After a number of cycles, inorganic trace pollutants may reach equilibrium and subsequent saturation in the water stream [30]. Distribution of TMEs during the coal combustion process has been extensively studied [17] [20] [31]-[39]. On the other hand, there are only a few studies describing accumulation of elements in gypsum or gypsum slurry [15] [16] [30] [40] [41] [42] [43].

Lignite burning Šoštanj thermal power plant (Šoštanj TPP, Slovenia) is studied in this paper. We previously examined the importance of particle size re- 
garding mercury accumulation in WFGD gypsum from a Šoštanj TPP. Grain size distribution revealed a significantly higher proportion of $\mathrm{Hg}$ in smaller particles where $12 \%$ of the finest fraction contains $63 \%$ of the mercury [28]. In the present work, in addition to mercury, the concentrations of 44 other trace and major elements (TMEs) were determined in various size fractions of gypsum. Instead of studying all water streams relating to the WFGD system, the focus was on particles in the gypsum slurry samples (gypsum). Although bulk gypsum is typically used to characterize gypsum samples, in our work all gypsum slurry samples were separated into fine (recirculated gypsum slurry) and coarse (mostly consisted of $\mathrm{CaSO}_{4} \cdot 2 \mathrm{H}_{2} \mathrm{O}$ ) fractions. Our study revealed several important findings with regards to the distribution pattern, accumulation and sources of TMEs in the different particle size fractions. We have had also emphasized the importance of proper sample preparation when separating gypsum slurry into fine and coarse fractions.

\section{Materials and Methods}

\subsection{Study Site}

To carry out the analysis and distribution pattern of TMEs, lignite burning Šoštanj TPP Slovenia have selected for the identification of TMEs. Šoštanj TPP used to have five power blocks with combined power of $775 \mathrm{MW}$. It uses lignite from the local mine Velenje as a fuel with a heating value of $9.5 \mathrm{MJ} \cdot \mathrm{kg}^{-1}$. The consumption rate is between 3.5 and 4.2 million tons per year. There are two WFGD units for removing $\mathrm{SO}_{2}$, the first covering blocks 1 through 4 , while the second covers block 5 (http://www.te-sostanj.si/en/presentation/history). In this study our main concern are focused on block 5. All WFGD systems use the wet limestone process with forced oxidation and are equipped with ESP.

\subsection{Sample Description}

Lignite samples (LIG) and three different gypsum slurries were taken from the batch of block 5, Šoštanj TPP. All samples were separately recorded, labelled and collected. The preparation procedures for those samples are described below (Section 2.2.1). The data of multi-elemental analyses for bulk gypsum (a mixture of finer and coarse fraction) and limestone were taken from previous work [28].

\subsubsection{Preparation of Lignite Sample}

LIG was sampled in 2012 from a conveyer belt during a normal working day to ensure representative sample. The combined mass of the obtained samples was $\sim 3 \mathrm{~kg}$. The samples were dried and maintained a fixed weight at $38^{\circ} \mathrm{C}$ for one week in an electric drier/oven (MEMMERT UFE 500). After the drying process, they were ground with a ball mill and sieved with a Fritsch Pulverisette 0 Vibratory Micro Mill to a particle size of less than $\sim 250 \mu \mathrm{m}$.

\subsubsection{Preparation of Gypsum Samples}

Three samples of gypsum slurry were drawn from the agitated tank of the 
WFGD absorber (main scrubber, block 5). Representative samples were taken, when the process in the desulphurisation scrubber was in a steady state. In this paper, the terms gypsum slurry, gypsum and slurry water are used. Gypsum slurry represents total slurry (liquid together with solids) while gypsum consists only of moist solid fraction (a mixture of coarse and finer fraction). The solid fraction in gypsum slurry is settled and slurry water represents the liquid above the solid fraction that contains dissolved pollutants together with small particles, typically not seen or only seen as an opaque solution. Each slurry was separated using size selective fraction into fine and coarse fractions. Two different separation techniques were adopted for this procedure:

1) In the first approach, separation of gypsum slurry particles with the help of a hydrocyclone (pilot version, laboratory set-up, Figure 1) into a fine fraction (FF) and coarse fraction (CF) labelled as TEŠ5-FF and TEŠ5-CF. Using centrifugal force, fractions were separated such that denser CF settles at the bottom (underflow, TEŠ5-CF) and a lighter FF at the top (overflow, TEŠ5-FF), of which the latter in actual WFGD hydrocyclone systems is recirculated back into the agitated tank as recirculated slurry. In addition, slurry water was also subjected for elemental analysis (TEŠ5- $\mathrm{W}_{1}$, TEŠ5- $\mathrm{W}_{2}$ ). Samples of the above process were carefully collected and stored in May 2013.

2) The second separation involved two samples. Gypsum slurries were homogenised by shaking, and left 72 hours to settle until two well-defined layers were formed. While the bottom layer consolidated rather quickly, it took several hours for the upper layer to separate particulates from clear water phases. After decantation, the water layer was extracted with a pipette yielding a creamy brown material. Using this approach, two particulate fractions were obtained, labelled as TEŠ5-FF1 and TEŠ5-CF1 for the first sample and TEŠ5-FF2 and TEŠ5-CF2 for the second sample. Samples were collected in December 2013 and January 2014. In this case, slurry water was not obtained for further analysis.

\subsubsection{Characterisation of Gypsum Samples}

\section{1) Grain size distribution}

Grain size distribution of samples was done using Microtrac PSA FRA 9200 which is based on Fraunhofer laser diffraction method. All fractions were subjected to air-dry and maintained constant weight at $38^{\circ} \mathrm{C}$ in an electric drier/oven (MEMMERT UFE 500). After drying, samples were homogenised in agate containers of a planetary mill (Fritsch planetary mill Pulverisette 7).

2) Morphological characteristic study using scanning electron microscopy (SEM)

Structure and morphological signature characteristics of samples (FF and CF of gypsum) were detailed studies with SEM (JEOL JSM-7600F) equipped with an energy dispersive spectrometer (EDS) (Oxford INCA 350). The samples were mounted and fixed using carbon tape and coated with amorphous carbon using an evaporation device (Balzers CED) before their size, morphology and chemical 


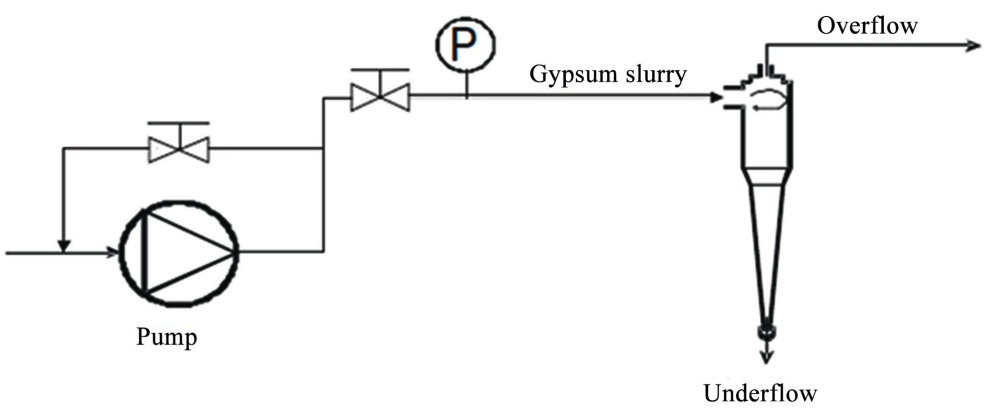

Figure 1. Scheme for separation of finer (overflow) and coarse fraction (underflow).

characterisation were analysed. The images were obtained with $5 \mathrm{kV}$ accelerating voltage and $0.1 \mathrm{pA}$ electron beam currents, and measured with an inside column Faraday cup.

3) Multi-elemental Analysis of Lignite, Process Water and Gypsum Samples Using $k_{0}$-INAA

Determination of major, minor and trace elements was carried out with $k_{0}$-standardisation method of instrumental neutron activation analysis $\left(k_{0}\right.$-INAA). For $k_{0}$-INAA purposes, homogenised samples $(\sim 150-200 \mathrm{mg})$ were sealed into pure polyethylene ampoules (SPRONK system, Netherland), stacked together in sandwich form with standard Al-0.1\%Au alloy (IRMM-530R alloy) and irradiated in the $250 \mathrm{~kW}$ TRIGA Mark II reactor of the Jožef Stefan Institute (JSI) in Ljubljana, Slovenia. In the $k_{0}$-INAA, the standard for all elements is Au. All relevant nuclear data for the method are summarized in the form of Excel file, which is available at http://www.kayzero.com/k0naa/k0naaorg/Nuclear_Data_SC/Entries/2016/1/11_ New_k0-data_Library_2015.html. Data are regularly updated and recommended to use by the $k_{0}$-NDSC ( $k_{0}$-Nuclear Data Subcommittee) as it is presented in Ref [44]. Depending on the purpose of the analysis, typically two irradiations were performed in the carousel facility of the TRIGA reactor at a thermal neutron flux of $1.1 \times 10^{12} \mathrm{~cm}^{-2} \cdot \mathrm{s}^{-1}$ : short irradiation (up to a few minutes) to determine elements via their corresponding short half-life radionuclides, and second irradiation (up to 12 hours) to determine elements via their corresponding medium/long half-life radionuclides. For QA/QC purposes, the certified reference material BCR-320R Channel Sediment was used. Our results we presented graphically on Figure 2, where good agreement between $k_{0}$-INAA data and certified values can be seen.

After irradiation and appropriate cooling time, the samples were measured on absolutely calibrated HPGe detectors ( $40 \%$ and $45 \%$ relative efficiency). For peak area evaluation, the HyperLab program was used. For elemental content determinations and effective solid angle calculations, the software package Kayzero for Windows was used [45] [46] [47].

The $k_{0}$-INAA at the Department of Environment Sciences of the JSI is accredited according ISO/IEC 17025:2005 since 2009 under accreditation certificate LP-090 awarded by Slovenian Accreditation (SA). The Annex to the ac- 
creditation certificate LP-090 dated on 21. March 2018 is available at http://www.slo-akreditacija.si/acreditation/institut-jozef-stefan/. Under the scope of accreditation, the $k_{0}$-INAA is accredited for 31 elements in different matrices as follows: soil, sediment, ores, sewage sludge, biological samples, foodstuffs and fuels.

\section{Results and Discussion}

The data obtained for total elemental concentrations and corresponding uncertainties in LIG sample, limestone, slurry waters, bulk and various CF and FF of gypsum are presented in Table 1 and Table 2 . In most papers, data are available for a limited number of elements, while the present study provides information for 45 elements, including some strategically important rare earth elements (REEs) that are rarely discussed. The results are concentrated and discussed based on 1) the properties of FF and CF of gypsum samples, 2) enrichment of elements in FF with respect to the CF of gypsum, 3) input of elements with limestone as a source of TMEs into the system, and 4) a comparison between FF and CF versus LIG, and evaluation among the different preparation procedures.

BCR-320R Channel Sediment

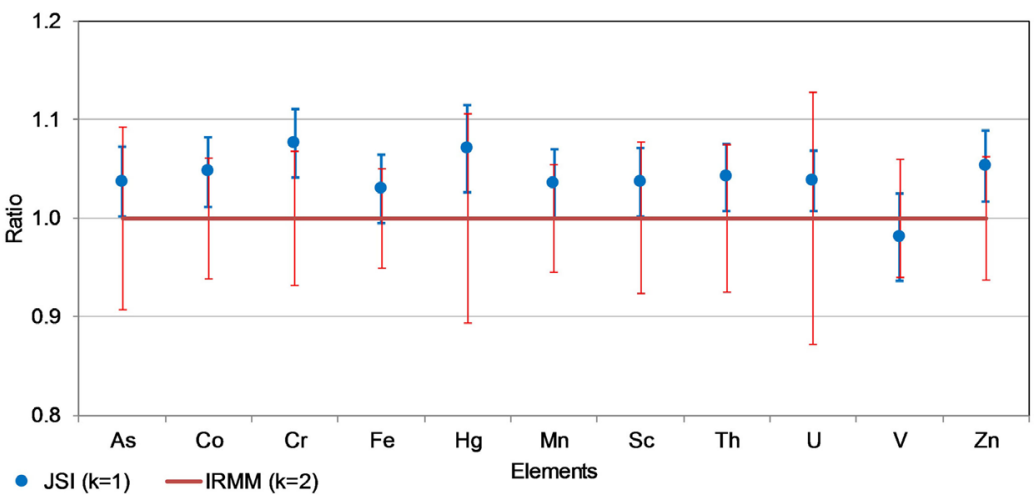

Figure 2. Comparison of data for BCR-320R obtained by $k_{0}$-INAA with IRMM data. The error bars for data obtained by $k_{0}$-INAA represent combined standard uncertainty (JSI (k $=1)$ ), while IRMM data are given with a $95 \%$ confidence interval $(\mathrm{k}=2)$.

Table 1. Elemental content with combined standard uncertainty $\left(\mathrm{mg} \cdot \mathrm{kg}^{-1}\right)$ in coal (LIG), limestone, slurry waters (FGD-W $\mathrm{W}_{1}$ and FGD-W $_{2}$ and in bulk gypsum obtained by $k_{0}$-instrumental neutron activation analyses $\left(k_{0}\right.$-INAA). Multi-elemental analysis was done for 45 elements where $\mathrm{Hg}$ in limestone and bulk gypsum were measured by CVAAS.

\begin{tabular}{|c|c|c|c|c|c|c|c|c|c|c|}
\hline \multicolumn{11}{|c|}{ Concentration of elements in different fractions and their uncertainties } \\
\hline & \multicolumn{2}{|c|}{ Lignite (LIG) } & \multicolumn{2}{|c|}{ Limestone } & \multicolumn{2}{|c|}{ FGD-W 1} & \multicolumn{2}{|c|}{ FGD-W 2} & \multicolumn{2}{|c|}{ Bulk gypsum } \\
\hline $\mathrm{Ag}$ & ${ }^{\mathrm{a}} 0.12$ & - & ${ }^{\mathrm{a}} 0.02$ & - & ${ }^{\mathrm{a}} 0.003$ & - & ${ }^{\mathrm{a}} 0.003$ & - & ${ }^{\mathrm{a}} 0.1$ & - \\
\hline $\mathrm{Al}$ & 22,200 & 800 & a 2430 & - & ${ }^{\mathrm{a}} 3.00$ & - & ${ }^{\mathrm{a}} 2.50$ & - & 7650 & 280 \\
\hline As & 8.19 & 0.30 & 1.32 & 0.05 & ${ }^{\mathrm{a}} 0.03$ & - & ${ }^{\mathrm{a}} 0.04$ & - & 7.52 & 0.27 \\
\hline $\mathrm{Au}$ & ${ }^{\mathrm{a}} 0.0008$ & - & ${ }^{\mathrm{a}} 0.0003$ & - & ${ }^{\mathrm{a}} 0.0002$ & - & ${ }^{\mathrm{a}} 0.0001$ & - & ${ }^{\mathrm{a}} 0.001$ & - \\
\hline $\mathrm{Ba}$ & 122 & 5 & 19.9 & 0.9 & ${ }^{\mathrm{a}} 0.20$ & - & ${ }^{\mathrm{a}} 0.15$ & - & 48.8 & 2.1 \\
\hline
\end{tabular}




\section{Continued}

\begin{tabular}{|c|c|c|c|c|c|c|c|c|c|c|}
\hline $\mathrm{Br}$ & 6.19 & 0.23 & 0.29 & 0.01 & 55.8 & 2.0 & 60.3 & 2.1 & 18.8 & 0.7 \\
\hline $\mathrm{Ca}$ & 19,400 & 700 & 365,000 & 13,000 & 519 & 25 & 544 & 25 & 200,000 & 7000 \\
\hline $\mathrm{Cd}$ & ${ }^{\mathrm{a}} 0.50$ & - & ${ }^{\mathrm{a}} 0.33$ & - & ${ }^{\mathrm{a}} 0.07$ & - & ${ }^{\mathrm{a}} 0.14$ & - & ${ }^{\mathrm{a}} 0.85$ & - \\
\hline $\mathrm{Ce}$ & 14.5 & 0.5 & 2.03 & 0.08 & ${ }^{\mathrm{a}} 0.01$ & - & ${ }^{\mathrm{a}} 0.01$ & - & 4.61 & 0.17 \\
\hline $\mathrm{Cl}$ & 69.9 & 7.4 & ${ }^{\mathrm{a}} 6.20$ & - & 962 & 35 & 958 & 34 & 409 & 16 \\
\hline Co & 3.07 & 0.11 & 0.37 & 0.01 & 0.082 & 0.003 & 0.066 & 0.003 & 1.04 & 0.04 \\
\hline $\mathrm{Cr}$ & 20.8 & 0.7 & 6.94 & 0.27 & ${ }^{\mathrm{a}} 0.01$ & - & ${ }^{\mathrm{a}} 0.005$ & - & 24.3 & 0.90 \\
\hline Cs & 3.26 & 0.11 & 0.34 & 0.01 & 0.0008 & 0.0002 & 0.0011 & 0.0002 & 1.38 & 0.05 \\
\hline Dy & ${ }^{\mathrm{a}} 0.35$ & - & 0.35 & 0.01 & ${ }^{\mathrm{a}} 0.02$ & - & ${ }^{\mathrm{a}} 0.02$ & - & 0.56 & 0.02 \\
\hline $\mathrm{Eu}$ & 0.31 & 0.01 & 0.06 & 0.01 & ${ }^{\mathrm{a}} 0.0002$ & - & ${ }^{\mathrm{a}} 0.0002$ & - & 0.11 & 0.01 \\
\hline $\mathrm{Fe}$ & 15,600 & 500 & 1060 & 40 & ${ }^{\mathrm{a}} 0.55$ & - & ${ }^{\mathrm{a}} 0.40$ & - & 5320 & 190 \\
\hline $\mathrm{Ga}$ & ${ }^{\mathrm{a}} 0.80$ & - & 0.45 & 0.03 & ${ }^{\mathrm{a}} 0.50$ & - & ${ }^{\mathrm{a}} 0.50$ & - & 2.91 & 0.12 \\
\hline Hf & 0.66 & 0.02 & 0.14 & 0.01 & ${ }^{\mathrm{a}} 0.0005$ & - & ${ }^{\mathrm{a}} 0.0001$ & - & 0.24 & 0.01 \\
\hline $\mathrm{Hg}$ & 0.119 & 0.02 & ${ }^{\mathrm{b}} 0.0054$ & 0.0005 & ${ }^{\mathrm{a}} 0.02$ & - & ${ }^{\mathrm{a}} 0.02$ & - & 0.95 & 0.09 \\
\hline I & ${ }^{\mathrm{a}} 5.00$ & - & ${ }^{\mathrm{a}} 0.95$ & - & 24.6 & 0.9 & 24.3 & 0.9 & 7.17 & 0.45 \\
\hline In & 1 & I & ${ }^{\mathrm{a}} 0.005$ & - & ${ }^{\mathrm{a}} 0.001$ & - & 0.002 & - & ${ }^{\mathrm{a}} 0.01$ & - \\
\hline $\mathrm{K}$ & 2890 & 110 & 383 & 15 & 53.4 & 8.5 & 57.1 & 9.1 & 1920 & 70 \\
\hline $\mathrm{La}$ & 7.34 & 0.27 & 1.49 & 0.06 & ${ }^{\mathrm{a}} 0.002$ & - & ${ }^{\mathrm{a}} 0.002$ & - & 3.18 & 0.12 \\
\hline $\mathrm{Mg}$ & 4160 & 240 & ${ }^{\mathrm{a}} 1380$ & - & 2600 & 90 & 2590 & 90 & 4450 & 180 \\
\hline $\mathrm{Mn}$ & 600 & 20 & 37.6 & 1.4 & 15.3 & 0.5 & 14.8 & 0.5 & 46.5 & 1.6 \\
\hline Mo & 11.3 & 0.5 & ${ }^{\mathrm{a}} 0.19$ & - & 0.40 & 0.02 & 0.41 & 0.02 & 2.61 & 0.23 \\
\hline $\mathrm{Na}$ & 1370 & 50 & 90.9 & 3.2 & 140 & 5 & 149 & 5 & 431 & 15 \\
\hline $\mathrm{Nd}$ & 6.92 & 0.32 & 2.30 & 0.17 & ${ }^{\mathrm{a}} 0.02$ & - & ${ }^{\mathrm{a}} 0.02$ & - & 3.72 & 0.35 \\
\hline $\mathbf{R b}$ & 25.5 & 0.9 & 2.84 & 0.18 & 0.12 & 0.01 & 0.16 & 0.01 & 13.6 & 0.5 \\
\hline$S$ & ${ }^{\mathrm{a}} 2450$ & - & ${ }^{\mathrm{a}} 6030$ & - & 3300 & 478 & 2980 & 479 & 143,000 & 14,600 \\
\hline $\mathrm{Sb}$ & 2.07 & 0.07 & 0.21 & 0.01 & 0.0060 & 0.0003 & 0.0064 & 0.0003 & 0.75 & 0.03 \\
\hline Sc & 4.74 & 0.13 & 0.42 & 0.02 & ${ }^{\mathrm{a}} 0.00004$ & - & ${ }^{\mathrm{a}} 0.00001$ & - & 1.57 & 0.06 \\
\hline $\mathrm{Se}$ & 0.79 & 0.03 & ${ }^{\mathrm{a}} 0.04$ & - & 0.23 & 0.01 & 0.23 & 0.01 & 8.37 & 0.30 \\
\hline Sm & 1.40 & 0.05 & 0.33 & 0.01 & ${ }^{\mathrm{a}} 0.004$ & - & ${ }^{\mathrm{a}} 0.004$ & - & 0.60 & 0.02 \\
\hline $\mathrm{Sr}$ & 103 & 4 & 366 & 13 & 2.20 & 0.13 & 2.71 & 0.13 & 168 & 7 \\
\hline $\mathrm{Ta}$ & 0.21 & 0.01 & 0.020 & 0.002 & ${ }^{\mathrm{a}} 0.0005$ & - & ${ }^{\mathrm{a}} 0.0005$ & - & 0.08 & 0.003 \\
\hline $\mathrm{Tb}$ & 0.19 & 0.01 & 0.052 & 0.002 & ${ }^{\mathrm{a}} 0.0005$ & - & ${ }^{\mathrm{a}} 0.0003$ & - & 0.087 & 0.003 \\
\hline Th & 2.88 & 0.10 & 0.32 & 0.01 & ${ }^{\mathrm{a}} 0.0005$ & - & ${ }^{\mathrm{a}} 0.0005$ & - & 0.99 & 0.04 \\
\hline $\mathrm{Ti}$ & 815 & 73 & a250 & - & ${ }^{\mathrm{a}} 14.0$ & - & ${ }^{\mathrm{a}} 13.0$ & - & 282 & 31 \\
\hline $\mathrm{U}$ & 8.94 & 0.32 & 4.55 & 0.16 & 0.13 & 0.01 & 0.103 & 0.004 & 5.11 & 0.18 \\
\hline $\mathrm{V}$ & 34.2 & 1.40 & 13.5 & 1.4 & 0.18 & 0.02 & 0.23 & 0.02 & 29.0 & 1.2 \\
\hline $\mathrm{W}$ & 0.80 & 0.08 & 0.04 & 0.01 & ${ }^{\mathrm{a}} 0.05$ & - & ${ }^{\mathrm{a}} 0.07$ & - & 0.29 & 0.02 \\
\hline $\mathrm{Yb}$ & 0.57 & 0.02 & 0.18 & 0.001 & ${ }^{\mathrm{a}} 0.001$ & - & ${ }^{\mathrm{a}} 0.001$ & - & 0.33 & 0.01 \\
\hline $\mathrm{Zn}$ & 49.0 & 1.70 & 4.74 & 0.21 & 0.22 & 0.01 & 0.08 & 0.01 & 30.9 & 1.1 \\
\hline $\mathrm{Zr}$ & ${ }^{\mathrm{a}} 14.5$ & - & ${ }^{a} 5.06$ & - & ${ }^{\mathrm{a}} 0.35$ & - & ${ }^{\mathrm{a}} 0.25$ & - & ${ }^{\mathrm{a}} 9.5$ & - \\
\hline
\end{tabular}

${ }^{\mathrm{a}}<$ LOD; results are given as LOD/2; ${ }^{\mathrm{b}}$ results obtained by CVAAS (Stergaršek et al., 2008). 
Table 2. Elemental content with combined standard uncertainty $\left(\mathrm{mg} \cdot \mathrm{kg}^{-1}\right)$ in gypsum samples (TEŠ5-FF, TEŠ5-CF, TEŠ5-FF1, TEŠ5-CF1, TEŠ5-FF2 and TEŠ5-CF2) obtained by $k_{0}$-instrumental neutron activation analyses. Multi-elemental analysis was done for 45 elements.

\begin{tabular}{|c|c|c|c|c|c|c|c|c|c|c|c|c|}
\hline \multirow[b]{2}{*}{$\mathrm{Ag}$} & \multicolumn{2}{|c|}{ TEŠ5-CF } & \multicolumn{2}{|c|}{ TEŠ5-FF } & \multicolumn{2}{|c|}{ TEŠ5-CF1 } & \multicolumn{2}{|c|}{ TEŠ5-FF1 } & \multicolumn{2}{|c|}{ TEŠ5-CF2 } & \multicolumn{2}{|c|}{ TEŠ5-FF2 } \\
\hline & ${ }^{\mathrm{a}} 0.07$ & - & ${ }^{\mathrm{a}} 0.21$ & - & ${ }^{\mathrm{a}} 0.04$ & - & ${ }^{\mathrm{a}} 0.27$ & - & ${ }^{\mathrm{a}} 0.04$ & - & ${ }^{\mathrm{a}} 0.33$ & - \\
\hline $\mathrm{Al}$ & 1000 & 40 & 52,100 & 1800 & 544 & 20 & 42,200 & 1500 & 650 & 23 & 67,500 & 2400 \\
\hline As & 0.93 & 0.04 & 39.4 & 1.4 & 0.74 & 0.03 & 42.5 & 1.5 & 0.60 & 0.02 & 52.6 & 1.9 \\
\hline $\mathrm{Au}$ & ${ }^{\mathrm{a}} 0.0003$ & - & ${ }^{\mathrm{a}} 0.001$ & - & ${ }^{\mathrm{a}} 0.0005$ & - & 0.0056 & 0.0006 & ${ }^{\mathrm{a}} 0.0003$ & - & 0.0073 & 0.0007 \\
\hline $\mathrm{Ba}$ & 11.0 & 0.9 & 262 & 11 & ${ }^{\mathrm{a}} 2.28$ & - & 177 & 10 & ${ }^{\mathrm{a}} 1.86$ & - & 294 & 16 \\
\hline $\mathrm{Br}$ & 8.01 & 0.28 & 35.1 & 1.2 & 14.6 & 0.5 & 249 & 9 & 13.2 & 0.5 & 408 & 14 \\
\hline $\mathrm{Ca}$ & 223,000 & 8000 & 144,000 & 5000 & 232,000 & 8200 & 118,000 & 4000 & 232,000 & 8000 & 43,100 & 1630 \\
\hline $\mathrm{Cd}$ & ${ }^{\mathrm{a}} 0.20$ & - & 9.58 & 0.51 & ${ }^{\mathrm{a}} 0.60$ & - & 8.27 & 1.44 & ${ }^{\mathrm{a}} 0.39$ & - & 11.7 & 1.5 \\
\hline $\mathrm{Ce}$ & 0.95 & 0.05 & 40.6 & 1.5 & 0.77 & 0.04 & 27.1 & 1.0 & 0.88 & 0.05 & 40.1 & 1.5 \\
\hline $\mathrm{Cl}$ & 147 & 6 & 568 & 22 & 266 & 10 & 4150 & 150 & 254 & 10 & 7760 & 280 \\
\hline Co & 0.16 & 0.01 & 8.39 & 0.30 & 0.13 & 0.01 & 7.07 & 0.25 & 0.13 & 0.01 & 10.7 & 0.4 \\
\hline $\mathrm{Cr}$ & 2.58 & 0.15 & 178 & 6 & 2.14 & 0.10 & 149 & 5 & 2.24 & 0.19 & 227 & 8 \\
\hline Cs & 0.18 & 0.01 & 10.4 & 0.4 & 0.108 & 0.004 & 8.51 & 0.30 & 0.13 & 0.01 & 13.5 & 0.5 \\
\hline Dy & 0.15 & 0.01 & 5.82 & 0.21 & 0.125 & 0.006 & 2.35 & 0.10 & 0.13 & 0.01 & 3.32 & 0.17 \\
\hline $\mathrm{Eu}$ & ${ }^{\mathrm{a}} 0.005$ & - & 1.20 & 0.05 & ${ }^{\mathrm{a}} 0.03$ & - & 0.63 & 0.03 & ${ }^{\mathrm{a}} 0.03$ & - & 0.91 & 0.06 \\
\hline $\mathrm{Fe}$ & 726 & 26 & 33,700 & 1200 & 482 & 17 & 34,100 & 1200 & 452 & 16 & 46,800 & 1700 \\
\hline $\mathrm{Ga}$ & ${ }^{\mathrm{a}} 0.33$ & - & 25.1 & 1.1 & ${ }^{\mathrm{a}} 0.17$ & - & ${ }^{\mathrm{a}} 3.26$ & - & ${ }^{\mathrm{a}} 0.15$ & - & 28.6 & 4.2 \\
\hline $\mathrm{Hf}$ & 0.043 & 0.003 & 1.50 & 0.06 & 0.036 & 0.003 & 1.44 & 0.05 & 0.050 & 0.002 & 2.33 & 0.08 \\
\hline $\mathrm{Hg}$ & 0.22 & 0.01 & 10.6 & 0.4 & 0.12 & 0.02 & 8.62 & 0.31 & 0.15 & 0.01 & 11.9 & 0.4 \\
\hline I & 3.14 & 0.13 & 22.5 & 0.9 & 1.40 & 0.09 & 42.5 & 2.0 & 1.22 & 0.09 & 112 & 4 \\
\hline In & ${ }^{\mathrm{a}} 0.002$ & - & 0.09 & 0.01 & ${ }^{\mathrm{a}} 0.005$ & - & ${ }^{\mathrm{a}} 0.03$ & - & ${ }^{\mathrm{a}} 0.005$ & - & 0.13 & 0.02 \\
\hline $\mathrm{K}$ & 300 & 20 & 14,500 & 500 & 179 & 9 & 10,500 & 400 & 176 & 9 & 17,600 & 600 \\
\hline $\mathrm{La}$ & 0.75 & 0.03 & 29.1 & 1.1 & 0.61 & 0.02 & 15.2 & 0.6 & 0.66 & 0.02 & 21.8 & 0.9 \\
\hline $\mathrm{Mg}$ & 1920 & 90 & 36,500 & 1400 & 1900 & 85 & 36,300 & 1300 & 1370 & 70 & 50,900 & 1900 \\
\hline $\mathrm{Mn}$ & 7.68 & 0.27 & 207 & 7 & 7.12 & 0.25 & 237 & 8 & 6.21 & 0.22 & 322 & 11 \\
\hline Mo & ${ }^{\mathrm{a}} 0.26$ & - & 3.87 & 1.17 & ${ }^{\mathrm{a}} 0.50$ & - & 26.5 & 1.6 & ${ }^{\mathrm{a}} 0.36$ & - & 43.2 & 2.4 \\
\hline $\mathrm{Na}$ & 58.9 & 2.1 & 1570 & 60 & 96.5 & 3.4 & 3500 & 100 & 109 & 4 & 4900 & 200 \\
\hline $\mathrm{Nd}$ & ${ }^{\mathrm{a}} 0.27$ & - & 25.2 & 1.1 & 1.18 & 0.15 & 10.6 & 0.8 & ${ }^{\mathrm{a}} 0.36$ & - & 15.7 & 1.4 \\
\hline $\mathrm{Rb}$ & 1.73 & 0.12 & 97.9 & 3.6 & 1.46 & 0.14 & 77.8 & 3.7 & 1.37 & 0.09 & 126 & 5 \\
\hline$S$ & - & - & - & - & 188,000 & 11,000 & 110,000 & 13,000 & 178,000 & 11,000 & 86,600 & 11,900 \\
\hline $\mathrm{Sb}$ & 0.120 & 0.005 & 4.68 & 0.17 & 0.097 & 0.004 & 5.68 & 0.22 & 0.108 & 0.005 & 8.69 & 0.31 \\
\hline $\mathrm{Sc}$ & 0.25 & 0.01 & 11.1 & 0.4 & 0.146 & 0.005 & 9.33 & 0.33 & 0.20 & 0.01 & 14.6 & 0.5 \\
\hline $\mathrm{Se}$ & 2.35 & 0.09 & 87.0 & 3.1 & 1.31 & 0.05 & 54.7 & 1.9 & 1.08 & 0.05 & 72.7 & 2.6 \\
\hline $\mathrm{Sm}$ & 0.15 & 0.01 & 5.90 & 0.22 & 0.131 & 0.006 & 2.76 & 0.18 & 0.14 & 0.01 & 4.55 & 0.38 \\
\hline $\mathrm{Sr}$ & 180 & 7 & 271 & 16 & 235 & 9 & 224 & 19 & 204 & 7 & 196 & 14 \\
\hline $\mathrm{Ta}$ & ${ }^{\mathrm{a}} 0.01$ & - & 0.50 & 0.02 & a 0.01 & - & 0.48 & 0.02 & ${ }^{\mathrm{a}} 0.005$ & - & 0.74 & 0.03 \\
\hline
\end{tabular}




\begin{tabular}{|c|c|c|c|c|c|c|c|c|c|c|c|c|}
\hline \multicolumn{13}{|c|}{ Continued } \\
\hline $\mathrm{Tb}$ & 0.021 & 0.002 & 0.88 & 0.03 & 0.022 & 0.001 & 0.41 & 0.01 & 0.020 & 0.001 & 0.57 & 0.02 \\
\hline Th & 0.16 & 0.01 & 6.43 & 0.23 & 0.124 & 0.005 & 6.49 & 0.23 & 0.11 & 0.01 & 9.36 & 0.33 \\
\hline $\mathrm{Ti}$ & a53.1 & - & 1910 & 130 & ${ }^{\mathrm{a}} 50.3$ & - & 1630 & 110 & ${ }^{\mathrm{a}} 48.5$ & - & 2630 & 150 \\
\hline $\mathrm{U}$ & 1.03 & 0.04 & 46.9 & 1.7 & 0.81 & 0.03 & 39.2 & 1.4 & 0.58 & 0.02 & 65.9 & 2.4 \\
\hline $\mathrm{V}$ & 4.65 & 0.20 & 227 & 8 & 3.16 & 0.15 & 199 & 7 & 3.27 & 0.16 & 352 & 13 \\
\hline W & ${ }^{\mathrm{a}} 0.06$ & - & 1.65 & 0.22 & ${ }^{\mathrm{a}} 0.05$ & - & ${ }^{\mathrm{a}} 0.80$ & - & ${ }^{\mathrm{a}} 0.05$ & - & ${ }^{\mathrm{a}} 1.04$ & - \\
\hline $\mathrm{Yb}$ & 0.074 & 0.004 & 3.19 & 0.12 & 0.073 & 0.004 & 1.71 & 0.07 & 0.073 & 0.003 & 2.46 & 0.10 \\
\hline $\mathrm{Zn}$ & 3.69 & 0.26 & 227 & 8 & 2.88 & 0.20 & 183 & 6 & 2.65 & 0.12 & 241 & 9 \\
\hline $\mathrm{Zr}$ & ${ }^{\mathrm{a}} 5.60$ & - & a34.9 & - & ${ }^{a} 5.01$ & - & ${ }^{\mathrm{a}} 31.0$ & - & ${ }^{\mathrm{a}} 4.41$ & - & 120 & 11 \\
\hline
\end{tabular}

\subsection{Properties of Finer and Coarse Fractions}

Determination of particle sizes by grain size distribution analyses are detailed in Figure 3. The differences in gypsum samples are most likely caused by mainly sample preparation procedures as well as different sampling time, sample locations and conditions within the WFGD system. The differences are more pronounced in the composition of the FF (Figure 3). FF of TEŠ5-FF contains a relatively high amount of CF (Figure 3(a)). This indicates that sedimentation technique provides better separation of $\mathrm{FF}$ and $\mathrm{CF}$ with respect to hydrocyclone separation. CF slightly differ among subsamples where TEŠ5-CF2 contains a bigger proportion of particles smaller than $50 \mu \mathrm{m}$ (Figure $3(\mathrm{c})$ ).

SEM technique gives insight into the structure of fine and coarse particles (Figure 4). Differences between the two fractions are clearly marked and highlighted. Mainly, $\mathrm{CaSO}_{4} \cdot 2 \mathrm{H}_{2} \mathrm{O}$ crystals represent the mainstream in CF (Figure 4(b)). Non-uniform size distribution of FF illustrates different structure, presumably consisting of unburned particles and different minerals originating from fly ash, agglomerates and precipitates (Figure 4(a) and Figure 4(c)). Bigger agglomerates are typically found in FF (Figure 4(d)). However, FF may also contain some bigger crystals of gypsum (Figure 4(a) and Figure 4(c)) that could be present as a consequence of the incomplete separation of the original gypsum slurry sample.

The bulk gypsum sample represents an average between $\mathrm{CF}$ and FF containing a lower amount of $\mathrm{CaSO}_{4} \cdot 2 \mathrm{H}_{2} \mathrm{O}$ with respect to the $\mathrm{CF}$. According to the previous study, FF represents only about $12 \%$ of the whole gypsum, while the majority of the sample is $\mathrm{CF}$ [28]. $\mathrm{CF}$ is predominantly in the form of $\mathrm{CaSO}_{4} \cdot 2 \mathrm{H}_{2} \mathrm{O}$ while in FF its proportion is much lower. The fine fraction TEŠ5-FF differs from TEŠ5-FF1 and TEŠ-FF2 according to a higher proportion of $\mathrm{CaSO}_{4} \cdot 2 \mathrm{H}_{2} \mathrm{O}$ due to the incomplete gypsum slurry separation into TEŠ5-FF and TEŠ5-CF as observed in Figure 3 (a). The possible explanation of this can be a lower amount of $\mathrm{CaSO}_{4} \cdot 2 \mathrm{H}_{2} \mathrm{O}$ in CF as compared with FF. Hence, Table 3 indicates far less $\mathrm{CaSO}_{4} \cdot 2 \mathrm{H}_{2} \mathrm{O}$ in TEŠ5-FF2 than in TEŠ5-FF and TEŠ5-FF1. However, less amount of $\mathrm{CaSO}_{4} \cdot 2 \mathrm{H}_{2} \mathrm{O}$ present in FF is consistent with lower particle size and increasing proportion of other spe- 
cies (elements) comprising in the sample. A small proportion of Ca could also be present as unconsumed $\mathrm{CaCO}_{3}$.

Table 3. Percentage of $\mathrm{Ca}$ and adequate proportion of $\mathrm{CaSO}_{4} \cdot 2 \mathrm{H}_{2} \mathrm{O}$ crystals in gypsum samples.

\begin{tabular}{ccc}
\hline Sample & $\begin{array}{c}\text { Percentage of calcium in } \\
\text { finer/coarse fraction (\%) }\end{array}$ & $\begin{array}{c}\text { Proportion of } \mathrm{CaSO}_{4} \cdot \mathbf{2} \mathrm{H}_{2} \mathrm{O} \\
\text { in gypsum (\%) }\end{array}$ \\
\hline Bulk gypsum & 20.4 & 87.6 \\
TEŠ5-CF & 22.3 & 95.6 \\
TEŠ5-FF & 14.4 & 61.9 \\
TEŠ5-CF1 & 23.2 & 99.6 \\
TEŠ5-FF1 & 11.8 & 50.5 \\
TEŠ5-CF2 & 23.2 & 99.6 \\
TEŠ5-FF2 & 4.31 & 18.5 \\
\hline
\end{tabular}

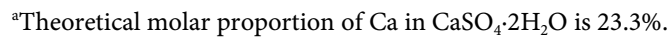
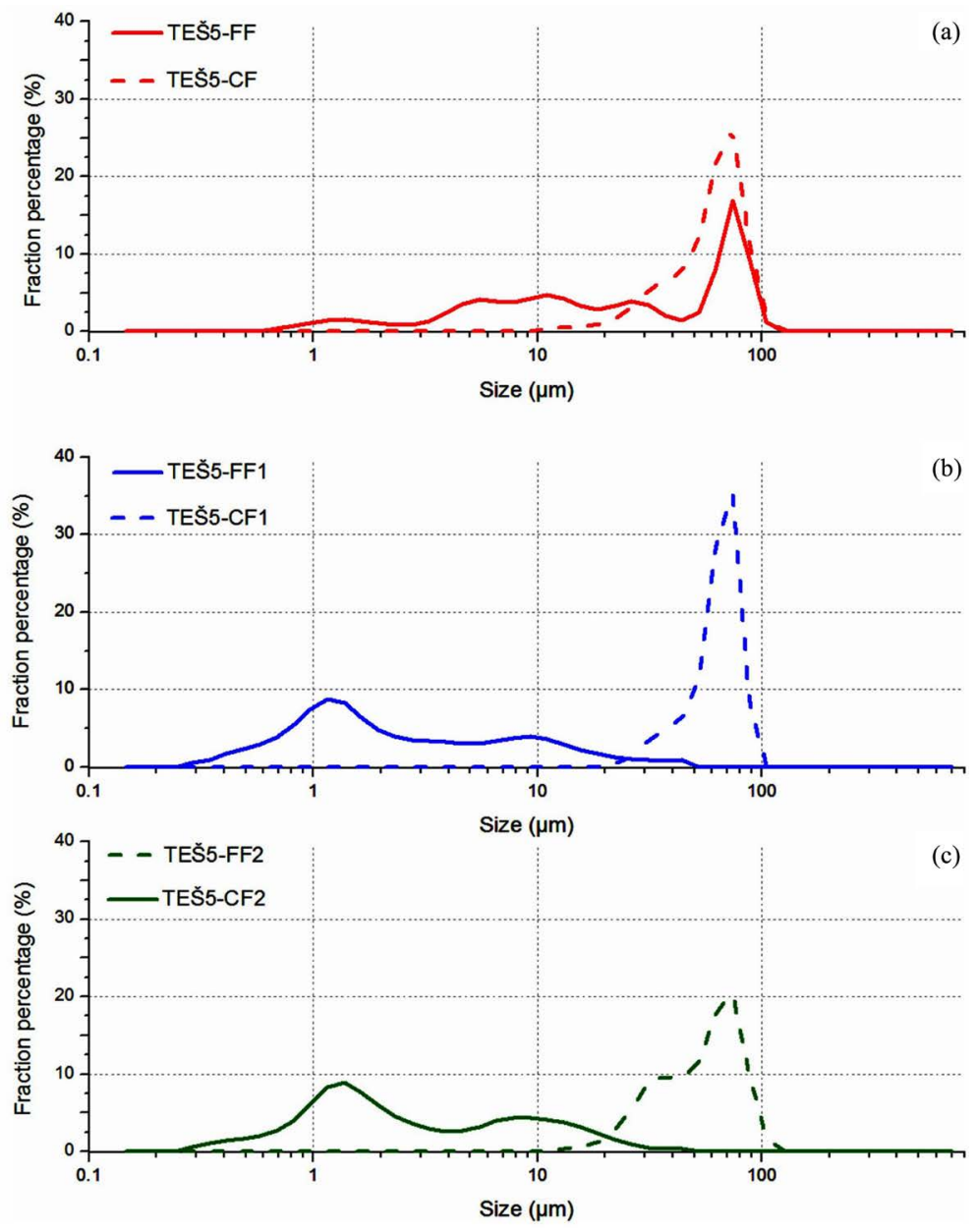

Figure 3. Distribution of particles in finer and coarse fractions from block 5: (a) separation by hydrocyclone (TEŠ5-FF, TEŠ5-CF) and (b), (c) separation by sedimentation (TEŠ5-FF1, TEŠ5-FF2, TEŠ5-CF1, TEŠ5-CF2). 

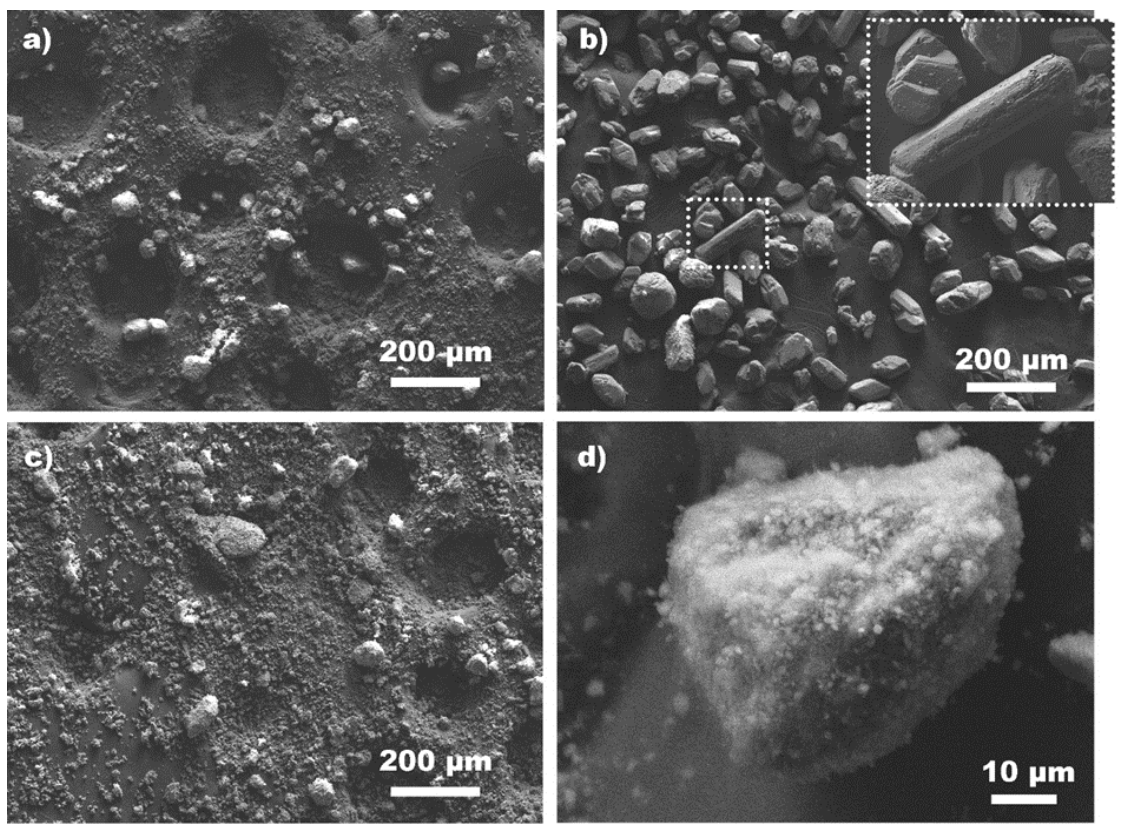

Figure 4. SEM images of solid particles in gypsum from block 5: (a) finer fractions TEŠ5-FF, (b) coarse fraction TEŠ5-CF, (c) finer fraction of TEŠ5-FF1, and (d) typical example of agglomerate present in both finer fractions.

\subsection{Enrichment of Elements in Finer Fraction}

Accumulation of TMEs in gypsum samples mainly depends on particle sizes. The elements are partitioned between FF and CF respectively (Figure 5). Most of the elements are considerably enriched in the FF, with some exceptions ( $\mathrm{Ca}$, $\mathrm{Sr}$ and S) that constitute the bulk of gypsum. Strontium is usually introduced in the system with limestone, and typically occurs as $\mathrm{SrCO}_{3}$ [22]. In general, the enrichment of elements in TEŠ5-FF is smaller with respect to TEŠ5-FF1 and TEŠ5-FF2. A larger proportion of bigger particles in the fine fraction TEŠ5-FF causing a "dilution" effect (Figure 3(a)). However, much higher enrichment was observed for most TMEs in TEŠ5-FF2 with respect to TEŠ5-FF1 and TEŠ5-FF fraction of gypsum, suggesting the importance of sampling and preparation procedures. Higher enrichment of most TMEs in TEŠ5-FF2 is consistent with Table 3, where the proportion of $\mathrm{CaSO}_{4} \cdot 2 \mathrm{H}_{2} \mathrm{O}$ is significantly lower as a consequence of other particles present in the sample.

Alkali elements show similar enrichment with the exception of $\mathrm{Na}$, while earth-alkaline elements show enrichment for $\mathrm{Mg}$ and $\mathrm{Ba}$, but not for $\mathrm{Ca}$ and $\mathrm{Sr}$ (Figure 5). In addition, Ba is highly enriched in FF of TEŠ5-FF2. Since the salts of alkali and earth alkali elements have solubility several orders of magnitude higher then salts of the transition elements, the precipitation reactions alone cannot explain these findings. This enrichment is mainly supported by adsorption. Aluminium is enriched in all FFs and is one of the most enriched elements. A small part is supplied with limestone, while most enters with fly ash that escapes the ESP and could be present as small aluminosilicate cenospheres with high specific surface for adsorption/condensation. On the other hand, it could 


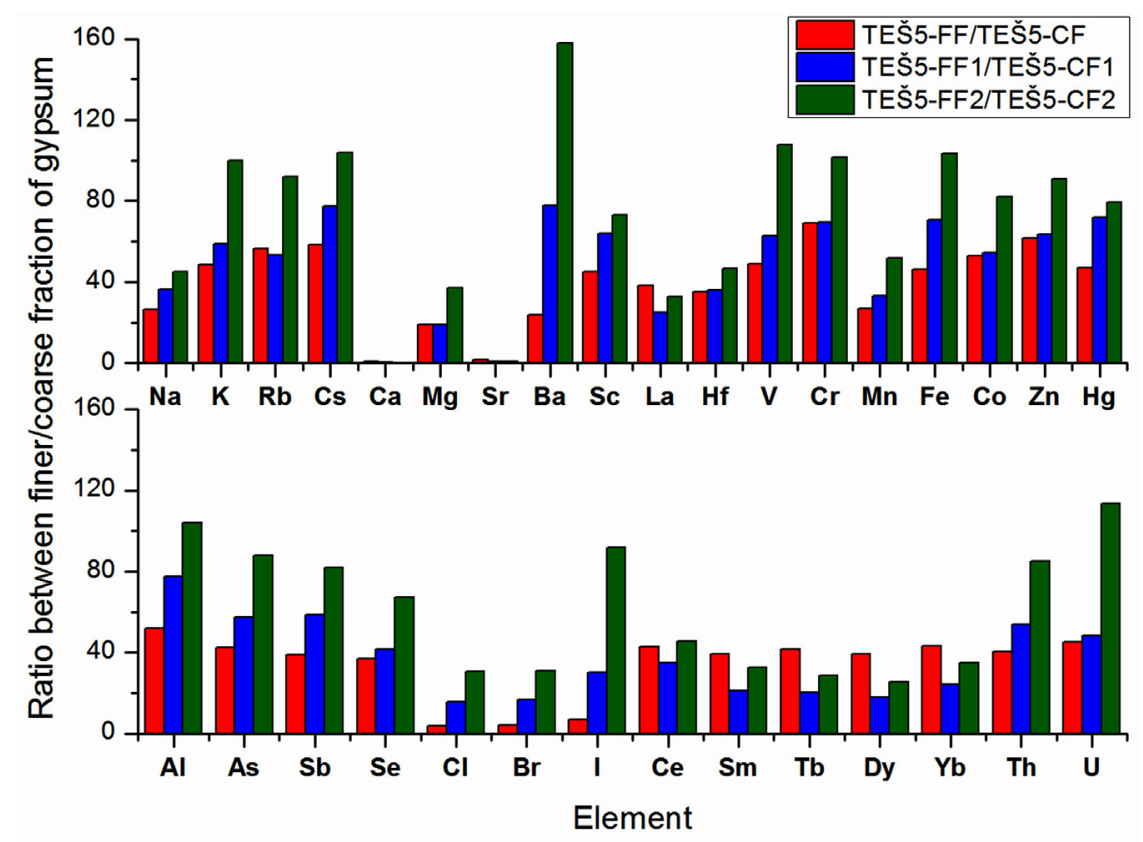

Figure 5. Enrichment of elements in the fine fraction compared to coarse fraction of block 5. Elements are ordered according to periodic system: alkali, alkaline earth metals and post-transition metals ( $\mathrm{Al}, \mathrm{Ga}, \mathrm{In})$, metalloids (As, Sb), non-metals ( $\mathrm{S}, \mathrm{Se})$, halogens $(\mathrm{Cl}, \mathrm{Br}, \mathrm{I})$, lanthanides and actinides.

enter as sulphate (oxide) aluminium species, where some are well soluble and therefore TMEs can be released [3] [43]. Al can be introduced by different insoluble, saturated species as well [43] [48]. As, Sb and Se show similar enrichment in all fractions. Enrichment of transition elements is comparable, except for La, $\mathrm{Hf}$ and $\mathrm{Mn}$. Mn, as a non-volatile element, is typically retained in bottom ash and therefore its presence in gypsum is mostly the consequence of limestone addition [22] and only minor amounts could enter with the smallest particles. In addition, $\mathrm{Mn}$ can form precipitates such as $\mathrm{MnO}_{2}$ in a WFGD slurry tank [24]. Lanthanides in TEŠ5-FF are slightly enriched compared to other FFs. Actinides, namely $T h$ and $U$, are similar in both blocks with the exception of finer fraction TEŠ5-FF2, where strong enrichment of both elements was observed.

The data of TMEs in slurry water are shown in Table 1 . The concentration of elements (TEŠ5- $\mathrm{W}_{1}$ and TEŠ5- $\mathrm{W}_{2}$ ) decreases within the following order: $\mathrm{Cl}, \mathrm{Mg}$, $\mathrm{Ca} \gg \mathrm{Na}, \mathrm{Br}, \mathrm{K}>\mathrm{I}, \mathrm{Mn}, \mathrm{Ti}>$ other elements. Different soluble complexes with halogens, $\mathrm{SO}_{4}^{2-}$ and $\mathrm{OH}$ - anions can form in a WFGD scrubber [43]. Some soluble elements (species) tend to concentrate through the recirculation process, where they could reach equilibrium, and possibly saturate, precipitate, or accumulate in FF afterwards. However, enrichment of halogens in FF with respect to $\mathrm{CF}$ is not significant, except for iodine in TEŠ5-FF2 (Figure 5). High concentrations of those elements in slurry water and in gypsum afterwards indicate their accumulation followed by formation of different insoluble species and/or adsorption process. Halogens that are well soluble with higher concentrations in slurry water enter in the system as volatile compounds, while other elements are 
mostly in the form of particulate matter and become mobile (released) in water media.

\subsection{Limestone as a Source of Elements}

As seen in Figure 5, most elements in FF are enriched relative to the CF. The composition of $\mathrm{CF}$ is similar to limestone, which is an important source of elements in the system. In the present study, CF of TEŠ5-CF1 was chosen for comparison with limestone (Figure 6) since it contains almost $100 \%$ of $\mathrm{CaSO}_{4} \cdot 2 \mathrm{H}_{2} \mathrm{O}$ according to calculations (Table 3). Most elements show higher concentrations in limestone with respect to CF. Halogens, $\mathrm{Hg}$ and Se show the opposite trend since they are not originating from limestone (Figure 6). During the desulphurisation process in a WFGD scrubber, elements present in limestone and those that enter with fly ash are included in different reactions, like the formation of different soluble/insoluble species, adsorption to particles and other oxidation/reduction processes. Elements entering with small particles alongside flue gases are of minor importance in $\mathrm{CF}$ where bigger crystals of $\mathrm{CaSO}_{4} \cdot 2 \mathrm{H}_{2} \mathrm{O}$ are a predominant matrix. However, the particle size is a very important parameter in determining the reactivity of limestones [22] and has an effect on the adsorption properties in $\mathrm{CF}$ and $\mathrm{FF}$.

\subsection{Comparison of Finer and Coarser Fractions versus Lignite}

In order to compare trend lines and concentration of elements that are enriched/depleted in all fractions of finer and coarser gypsum, concentrations of elements in different samples are shown in the same graph (Figure 7). Similar behaviour for most of the elements is observed; however some distinct differences related to $\mathrm{Br}, \mathrm{Cl}$, and I are seen. Concentrations of $\mathrm{Cl}, \mathrm{Br}$ and $\mathrm{I}$ in the $\mathrm{FF}$ of TEŠ5-FF are close to the trend line itself, following the predicted concentration ratios between FF and lignite samples (Figure 7). On the other hand, much higher concentrations of these elements are present in the other FF of block 5 . Similarly, all CFs (TEŠ5-CF, TEŠ5-CF1 and TEŠ5-CF2) show that $\mathrm{Br}, \mathrm{Cl}$ and I are located significantly higher with respect to the concentrations in coal and according to the other elements present in CF. CFs with a majority of Ca$\mathrm{SO}_{4} \cdot 2 \mathrm{H}_{2} \mathrm{O}$ seem to be a relatively efficient matrix for removal of halogens, whereas high retention is even more apparent in FFs, indicating greater accumulation with possible binding and/or reactions with other elements, and adsorption onto the minerals or to smaller crystals of gypsum. With respect to the position of trend lines, it is obvious that TEŠ5-FF2 contains higher concentrations of most TMEs, while within CFs there are no such differences between.

Among the most interesting features is high accumulation/retention of $\mathrm{Hg}$ and Se in all gypsum fractions regarding coal. Se mainly condenses on fly ash particles, while $\mathrm{Hg}$ is found as volatile species in flue gas [20]. Concentrations of Se and $\mathrm{Hg}$ in the particles leaving the ESP are higher in medium to fine fraction. In the gypsum, $\mathrm{Se}$ is suggested to be in oxidation state $\mathrm{Se}(\mathrm{IV})$ [49]. $\mathrm{SeO}_{2}$ is a 


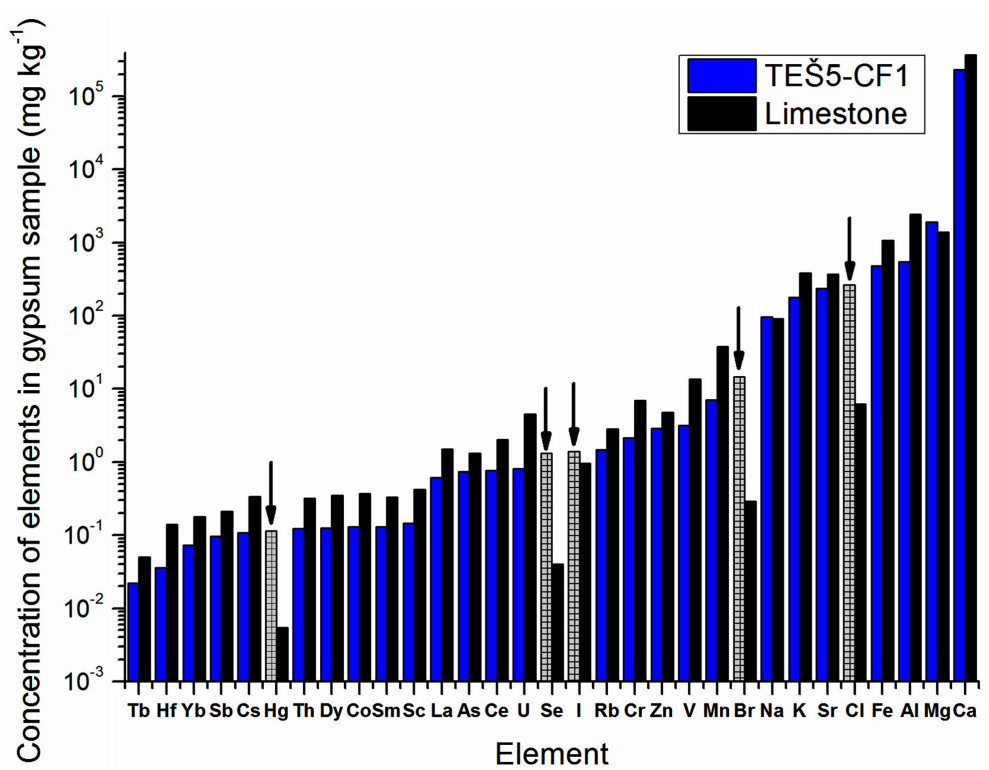

Figure 6. Concentration of elements in limestone and in coarse fraction of gypsum (TEŠ5-CF1) are present at the same graph indicating similarities in composition. Black arrows highlight the elements entering as a consequence of the coal combustion.

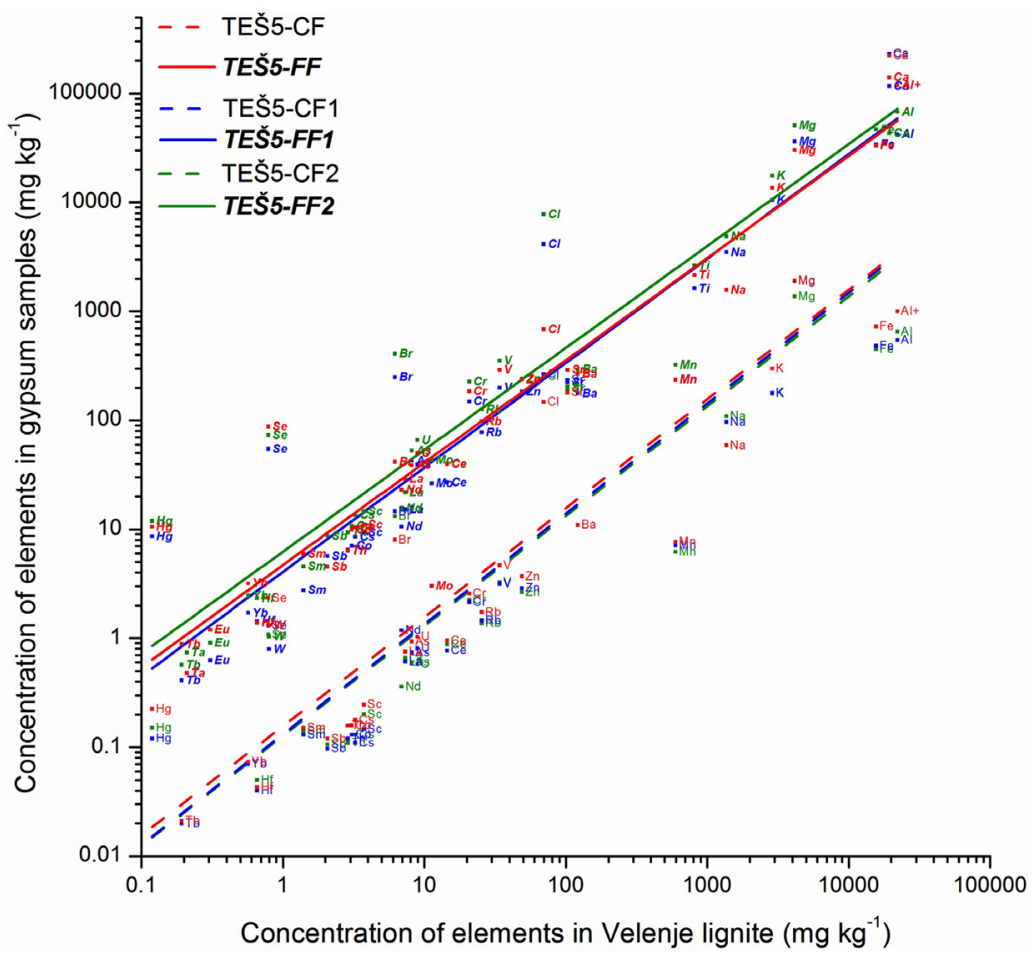

Figure 7. Concentration of elements in the Velenje lignite versus concentration of elements in all six finer and coarse fractions of gypsum (TEŠ5-FF, TEŠ5-CF, TEŠ5-FF1, TEŠ5-CF1, TEŠ5-FF2 and TEŠ5-CF2).

predominant species in flue gas that combines with lime in the scrubber to form $\mathrm{CaSeO}_{3}$ [50]. Another explanation for Se accumulation is attributed to its presence in gypsum as calcium selenatedihydrate $\left(\mathrm{CaSeO}_{4} \cdot 2 \mathrm{H}_{2} \mathrm{O}\right)$, which has similar 
properties as $\mathrm{CaSO}_{4} \cdot 2 \mathrm{H}_{2} \mathrm{O}$ [51] [52] [53] [54]. In the case of $\mathrm{Hg}$, various mercury compounds have been suggested to be present in gypsum, such as $\mathrm{Hg}-\mathrm{Cl}$ compounds, $\mathrm{HgS}, \mathrm{HgO}, \mathrm{Hg}_{-} \mathrm{SO}_{4}$, etc. [25] [42] [48] [55] [56] [57] [58]. Although $\mathrm{Hg}$ and Se form stable Hg-Se compounds, e.g. in biological systems [59], this has not been proven in WFGD gypsum so far [60]. $\mathrm{Fe}$ and $\mathrm{Al}$ may also have an important role in the adsorption of $\mathrm{Hg}$ to $\mathrm{Fe} / \mathrm{Al}$ (oxides/hydroxides) in the WFGD system [27] [29] [48].

In general, conditions are expected to be constant during the coal combustion process and the partitioning of elements in air pollution control devices (APCDs). However, sampling procedure itself and separation of gypsum into different fractions are important factors affecting partitioning in finer and coarser fractions of gypsum samples. Improved separation procedures and further investigations are needed to understand better the species formed, and to explain reactions present in a WFGD boiler. Identification of different species there would help in understanding the chemistry and enrichment/depletion process of elements.

\section{Conclusion}

The presence of TMEs in gypsum is primarily related to 1) small size fraction of fly ash not retained by the particle control devices, 2) volatile elements (e.g. Hg, Se and halogens) that are highly accumulated in the WFGD with respect to coal 3) introduction of limestone as an additional source of TMEs (e.g. $\mathrm{Mg}, \mathrm{Ca}, \mathrm{Sr}$ ) associated mostly with CF, 4) and the conditions present in a WFGD scrubber (e.g. oxidation-reduction, temperature, $\mathrm{pH}$, etc.). In general, the concentrations of TMEs in the $\mathrm{CF}$ and $\mathrm{FF}$ of gypsum varied, demonstrating the importance of particle size. Small particles retain much higher concentrations of most elements, especially $\mathrm{Hg}$ and $\mathrm{Se}$, which are highly enriched relative to their occurrence in coal. FF represents a small mass portion in the gypsum as a whole (about 10\%), but contains a large proportion of TMEs. Removal of fine gypsum fraction in the process of recirculation of gypsum slurry therefore represents one of the possible cost-effective remediation technologies. Thus, the appropriate approach based on the removal of the smallest size fraction of gypsum could eliminate most TMEs. Finally, the study also showed that the methodologies for sampling and separation of gypsum particle sizes need to be standardized in order to assure comparability of the results. Moreover, concentrations of TMEs in coal (lignite), limestone, fly ash and various size fractions of gypsum could provide a good indication of the removal efficiency of APCDs.

\section{Acknowledgements}

This work was funded by the Slovenian Research Agency program P1-0143 and project L1-5446 and the young researchers program. The study was also supported by the EMPIR MercOx project (16ENV01). We thank the Šoštanj thermal power plant for permitting us to obtain samples. 


\section{Conflicts of Interest}

The authors declare no conflicts of interest regarding the publication of this paper.

\section{References}

[1] Nriagu, J.O. and Pacyna, J.M. (1988) Quantitative Assessment of Worldwide Contamination of Air, Water and Soils by Trace Metals. Nature, 333, 134-139. https://doi.org/10.1038/333134a0

[2] Nalbandian, H. (2012) Trace Element Emissions from Coal. IEA Clean Coal Centre Reports.

[3] Querol, X., Fernández-Turiel, J. and López-Soler, A. (1995) Trace Elements in Coal and Their Behaviour during Combustion in a Large Power Station. Fuel, 74, 331-343. https://doi.org/10.1016/0016-2361(95)93464-O

[4] Querol, X., Juan, R., Lopez-Soler, A., Fernandez-Turiel, J.L. and Ruiz, C.R. (1996) Mobility of Trace Elements from Coal and Combustion Wastes. Fuel, 75, 821-838. https://doi.org/10.1016/0016-2361(96)00027-0

[5] Yudovich, Y. and Ketris, M.P. (2005) Mercury in Coal: A Review: Part 1. Geochemistry. International Journal of Coal Geology, 62, 107-134. https://doi.org/10.1016/j.coal.2004.11.002

[6] Mukherjee, A.B., Zevenhoven, R., Bhattacharya, P., Sajwan, K.S. and Kikuchi, R. (2008) Mercury Flow via Coal and Coal Utilization By-Products: A Global Perspective. Resources, Conservation and Recycling, 52, 571-591. https://doi.org/10.1016/j.resconrec.2007.09.002

[7] Vejahati, F., Xu, Z. and Gupta, R. (2010) Trace Elements in Coal: Associations with Coal and Minerals and Their Behavior during Coal Utilization-A Review. Fuel, 89, 904-911. https://doi.org/10.1016/j.fuel.2009.06.013

[8] Xu, M., Yan, R., Zheng, C., Qiao, Y., Han, J. and Sheng, C. (2004) Status of Trace Element Emission in a Coal Combustion Process: A Review. Fuel Processing Technology, 85, 215-237. https://doi.org/10.1016/S0378-3820(03)00174-7

[9] Clarke, L.B. and Sloss, L.L. (1992) Trace Elements from Coal Combustion and Gasification. IEACR/49, IEA Coal Research, London.

[10] Klein, D.H., Andren, A.W., Carter, J.A., Emery, J.F., Feldman, C., Fulkerson, W., Lyon, W.S., Ogle, J.C. and Talmi, Y. (2009) Mercury-Selenium Compounds and Their Toxicological Significance: Toward a Molecular Understanding of the Mercury-Selenium Antagonism. Environmental Toxicology and Chemistry/SETAC, 28, 1567-1577. https://doi.org/10.1897/08-375.1

[11] Meij, R. (1994) Trace Element Behavior in Coal-Fired Power Plants. Fuel Processing Technology, 39, 199-217. https://doi.org/10.1016/0378-3820(94)90180-5

[12] Galbreath, K.C. and Zygarlicke, C.J. (2000) Mercury Transformations in Coal Combustion Flue Gas. Fuel Processing Technology, 65, 289-310. https://doi.org/10.1016/S0378-3820(99)00102-2

[13] Helble, J.J. and Sarofirm, A.F. (1993) Trace Elemetn Behaviour during Coal Combustion. Preprints of Papers - American Chemical Society, Division of Fuel Chemistry, 38, 257-264.

[14] Meij, R. (1992) Analysis of Coal and Its By-Products. World Scientific Publishing Co., Singapore, 299-318.

[15] Liu, Y.K., Zhuo, Y.Q., Zhu, Z.W. and Chen, C.H. (2013) Leaching Characteristics of 
Trace Elements in Desulphurization Gypsum from a Coal-Fired Power Plant. Cleaner Combustion and Sustainable World, 377-385. https://doi.org/10.1007/978-3-642-30445-3_53

[16] Álvarez-Ayuso, E., Querol, X. and Tomás, A. (2006) Environmental Impact of a Coal Combustion-Desulphurisation Plant: Abatement Capacity of Desulphurisation Process and Environmental Characterisation of Combustion By-Products. Chemosphere, 65, 2009-2017. https://doi.org/10.1016/j.chemosphere.2006.06.070

[17] López-Antón, M.A., Díaz-Somoano, M., Ochoa-González, R. and Martínez-Tarazona, M.R. (2011) Distribution of Trace Elements from a Coal Burned in Two Different Spanish Power Stations. Industrial and Engineering Chemistry Research, 50, 12208-12216. https://doi.org/10.1021/ie2018542

[18] Bunt, J.R. and Waanders, F.B. (2010) Trace Element Behaviour in the Sasol-Lurgi Fixed-Bed Dry-Bottom Gasifier. Part 3 The Non-Volatile Elements: Ba, Co, Cr, Mn, and V. Fuel, 89, 537-548.

[19] Galbreath, K.C., Toman, D.L., Zygarlicke, C.J. and Pavlish, J.H. (2000) Trace Element Partitioning and Transformations during Combustion of Bituminous and Subbituminous U.S. Coals in a 7-kW Combustion System. Energy \& Fuels, 14, 1265-1279.

[20] Otero-Rey, J.R., López-Vilariño, J.M., Moreda-Piñeiro, J., Alonso-Rodríguez, E., Muniategui-Lorenzo, S., López-Mahía, P. and Prada-Rodríguez, D. (2003) As, Hg, and Se Flue Gas Sampling in a Coal-Fired Power Plant and Their Fate during Coal Combustion. Environmental Science and Technology, 37, 5262-5267. https://doi.org/10.1021/es020949g

[21] Pavlish, J.H., Sondreal, E.A., Mann, M.D., Olson, E.S., Galbreath, K.C., Laudal, D.L. and Benson, S.A. (2003) Status Review of Mercury Control Options for Coal-Fired Power Plants. Fuel Processing Technology, 82, 89-165. https://doi.org/10.1016/S0378-3820(03)00059-6

[22] Ochoa-González, R., Díaz-Somoano, M. and Martínez-Tarazona, M.R. (2013) Influence of Limestone Characteristics on Mercury Re-Emission in WFGD Systems. Environmental Science \& Technology, 47, 2974-2981. https://doi.org/10.1021/es304090e

[23] Stergaršek, A., Horvat, M., Frkal, P. and Stergaršek, J. (2010) Removal of $\mathrm{Hg}^{0}$ from Flue Gases in Wet FGD by Catalytic Oxidation with Air-An Experimental Study. Fuel, 89, 3167-3177. https://doi.org/10.1016/j.fuel.2010.04.006

[24] Stergaršek, A., Horvat, M., Frkal, P., Ribeiro Guevara, S. and Kocjančič, R. (2013) Removal of $\mathrm{Hg}^{0}$ in Wet FGD by Catalytic Oxidation with Air-A Contribution to the Development of a Process Chemical Model. Fuel, 107, 183-191. https://doi.org/10.1016/j.fuel.2012.08.001

[25] Liu, X., Wang, S., Zhang, L., Wu, Y., Duan, L. and Hao, J. (2013) Speciation of Mercury in FGD Gypsum and Mercury Emission during the Wallboard Production in China. Fuel, 111, 621-627.

[26] Heebink, L.V. and Hassett, D.J. (2005) Mercury Release from FGD. Fuel, 84, 1372-1377. https://doi.org/10.1016/j.fuel.2004.06.040

[27] Kairies, C.L, Schroeder, K.T. and Cardone, C.R. (2006) Mercury in Gypsum Produced from Flue Gas Desulfurization. Fuel, 85, 2530-2536. https://doi.org/10.1016/j.fuel.2006.04.027

[28] Stergaršek, A., Horvat, M., Kotnik, J., Tratnik, J., Frkal, P., Kocman, D., Jaćimović, R., Fajon, V., Ponikvar, M., Hrastel, I., Lenart, J., Debeljak, B. and Čujež, M. (2008) The Role of Flue Gas Desulphurisation in Mercury Speciation and Distribution in a 
Lignite Burning Power Plant. Fuel, 87, 3504-3512.

https://doi.org/10.1016/j.fuel.2008.06.003

[29] Beatty, W.L., Schroeder, K. and Beatty, C.L.K. (2012) Mineralogical Associations of Mercury in FGD Products. Energy \& Fuels, 26, 3399-3406.

https://doi.org/10.1021/ef300033u

[30] Córdoba, P., Font, O., Izquierdo, M., Querol, X., Tobías, A., López-Antón, M.A., Ochoa-Gonzalez, R., Díaz-Somoano, M., Martínez-Tarazona, M.R., Ayora, C, Leiva, C., Fernández, C. and Giménez, A. (2011) Enrichment of Inorganic Trace Pollutants in Re-Circulated Water Streams from a Wet Limestone Flue Gas Desulphurisation System in Two Coal Power Plants. Fuel Processing Technology, 92, 1764-1775. https://doi.org/10.1016/j.fuproc.2011.04.025

[31] Spears, D.A. and Martinez-Tarrazona, M.R. (2004) Trace Elements in Combustion Residues from a UK Power Station. Fuel, 83, 2265-2270.

https://doi.org/10.1016/j.fuel.2004.06.025

[32] Li, Z., Clemens, A.H., Moore, T.A., Gong, D., Weaver, S.D. and Eby, N. (2005) Partitioning Behaviour of Trace Elements in a Stoker-Fired Combustion Unit: An Example Using Bituminous Coals from the Greymouth Coalfield (Cretaceous), New Zealand. International Journal of Coal Geology, 63, 98-116. https://doi.org/10.1016/j.coal.2005.02.007

[33] Tang, Q., Liu, G., Yan, Z. and Sun, R. (2012) Distribution and Fate of Environmentally Sensitive Elements (Arsenic, Mercury, Stibium and Selenium) in Coal-Fired Power Plants at Huainan, Anhui, China. Fuel, 95, 334-339. https://doi.org/10.1016/j.fuel.2011.12.052

[34] Bhangare, R.C., Ajmal, P.Y., Sahu, S.K., Pandit, G.G. and Puranik, V.D. (2011) Distribution of Trace Elements in Coal and Combustion Residues from Five Thermal Power Plants in India. International Journal of Coal Geology, 86, 349-356. https://doi.org/10.1016/j.coal.2011.03.008

[35] Tang, Q., Liu, G., Yan, Z. and Sun, R. (2013) Distribution of Trace Elements in Feed Coal and Combustion Residues from Two Coal-Fired Power Plants at Huainan, Anhui, China. Fuel, 107, 315-322. https://doi.org/10.1016/j.fuel.2013.01.009

[36] Li, J., Zhuang, X., Querol, X., Font, O., Moreno, N. and Zhou, J. (2012) Environmental Geochemistry of the Feed Coals and Their Combustion By-Products from Two Coal-Fired Power Plants in Xinjiang Province, Northwest China. Fuel, 95, 446-456. https://doi.org/10.1016/j.fuel.2011.10.025

[37] Swanson, S.M., Engle, M.A., Ruppert, L.F., Affolter, R.H. and Jones, K.B. (2013) Partitioning of Selected Trace Elements in Coal Combustion Products from Two Coal-Burning Power Plants in the United States. International Journal of Coal Geology, 113, 116-126. https://doi.org/10.1016/j.coal.2012.08.010

[38] Córdoba, P., Ochoa-Gonzalez, R., Font, O., Izquierdo, M., Querol, X., Leiva, C., López-Antón, M.A., Díaz-Somoano, M., Rosa Martinez-Tarazona, M., Fernandez, C. and Tomás, A. (2012) Partitioning of Trace Inorganic Elements in a Coal-Fired Power Plant Equipped with a Wet Flue Gas Desulphurisation System. Fuel, 92, 145-157. https://doi.org/10.1016/j.fuel.2011.07.025

[39] Esenlik, S., Karayigit, A.I., Bulut, Y., Querol, X., Alastuey, A. and Font, O. (2006) Element Behaviour during Combustion in Coal-Fired Orhaneli Power Plant, Bursa-Turkey. Geologica Acta, 4, 439-449.

[40] Sun, M., Cheng, G., Lu, R., Tang, T., Baig S.A. and Xu, X. (2014) The Relationship between Speciation and Release Ability of Mercury in Flue Gas Desulfurization (FGD) Gypsum. Fuel, 125, 66-72. https://doi.org/10.1016/j.fuel.2014.02.012 
[41] Hao, Y., Wu, S., Pan, Y., Li, Q., Zhou, J., Xu, Y. and Qian, G. (2016) Characterization and Leaching Toxicities of Mercury in Flue Gas Desulfurization Gypsum from Coal-Fired Power Plants in China. Fuel, 177, 157-163. https://doi.org/10.1016/j.fuel.2016.02.091

[42] Zhu, Z., Zhuo, Y., Fan, Y. and Wang, Z. (2016) Fate of Mercury in Flue Gas Desulfurization Gypsum Determined by Temperature Programmed Decomposition and Sequential Chemical Extraction. Journal of Environmental Sciences, 43, 169-176. https://doi.org/10.1016/j.jes.2015.09.011

[43] Córdoba, P., Castro, I., Maroto-Valer, M. and Querol, X. (2015) The Potential Leaching and Mobilization of Trace Elements from FGD-Gypsum of a Coal-Fired Power Plant under Water Re-Circulation Conditions. Journal of Environmental Sciences, 32, 72-80. https://doi.org/10.1016/j.jes.2014.11.009

[44] Jaćimović, R., De Corte, F., Kennedy, G., Vermaercke, P. and Revay, Z. (2014) The 2012 Recommended $k_{0}$ Database. Journal of Radioanalytical and Nuclear Chemistry, 300, 589-592. https://doi.org/10.1007/s10967-014-3085-2

[45] Smodiš, B., Jaćimović, R., Medin, G. and Jovanović, S. (1993) Instrumental Neutron Activation Analysis of Sediment Reference Materials Using the $k_{0}$-Standardization Method. Journal of Radioanalytical and Nuclear Chemistry, 169, 177-185. https://doi.org/10.1007/BF02046792

[46] Jaćimović, R., Smodiš, B., Bučar, T. and Stegnar, P. (2003) $k_{0}$-NAA Quality Assessment by Analysis of Different Certified Reference Materials Using the KAYZERO/SOLCOI Software. Journal of Radioanalytical and Nuclear Chemistry, 257, 659-663. https://doi.org/10.1023/A:1026116916580

[47] Xilei, L., Corte, F., Moens, L., Simonits, A. and Hoste, J. (1984) Computer-Assisted Reactor NAA of Geological and Other Reference Materials, Using the $k_{0}$-Standardization Method: Evaluation of the Accuracy. Journal of Radioanalytical and Nuclear Chemistry, 81, 333-343. https://doi.org/10.1007/BF02135386

[48] Ochoa González, R., Díaz-Somoano, M., López Antón, M.A. and Martínez-Tarazona, M.R. (2012) Effect of Adding Aluminum Salts to Wet FGD Systems upon the Stabilization of Mercury. Fuel, 96, 568-571. https://doi.org/10.1016/j.fuel.2012.01.054

[49] Al-Abed, S.R., Jegadeesan, G., Scheckel, K.G. and Tolaymat, T. (2008) Speciation, Characterization, and Mobility of As, Se, and Hg in Flue Gas Desulphurization Residues. Environmental Science \& Technology, 42, 1693-1698. https://doi.org/10.1021/es702479n

[50] Huggins, F.E., Senior, C.L., Chu, P., Ladwig, K. and Huffman, G.P. (2007) Selenium and Arsenic Speciation in Fly Ash from Full-Scale Coal-Burning Utility Plants. Environmental Science \& Technology, 41, 3284-3289. https://doi.org/10.1021/es062069y

[51] Freyer, D. and Voigt, W. (2003) Crystallization and Phase Stability of $\mathrm{CaSO}_{4}$ and $\mathrm{CaSO}_{4}$-Based Salts. Monatshefte fur Chemie, 134, 693-719.

[52] Krüger, R.R. and Abriel, W. (1991) Growth and Structure Refinement of Ca$\mathrm{SeO}_{4} \cdot 2 \mathrm{H}_{2} \mathrm{O}$. Acta Crystallographica Section C, 47, 1958-1959.

[53] Pedersen, B.F. and Semmingsen, D. (1982) Neutron Diffraction Refinement of the Structure of Gypsum CaSO ${ }_{4} \cdot 2 \mathrm{H}_{2} \mathrm{O}$. Acta Crystallographica Section B, 38, 1074-1077.

[54] Fernández-González, A., Andara, A., Alía, J.M. and Prieto, M. (2006) Miscibility in the $\mathrm{CaSO}_{4} \cdot 2 \mathrm{H}_{2} \mathrm{O}-\mathrm{CaSeO}_{4} \cdot 2 \mathrm{H}_{2} \mathrm{O}$ System: Implications for the Crystallisation and Dehydration Behaviour. Chemical Geology, 225, 256-265.

https://doi.org/10.1016/j.chemgeo.2005.08.019 
[55] Sedlar, M., Pavlin, M., Jaćimović, R., Stergaršek, A., Frkal, P. and Horvat, M. (2015) Temperature Fractionation (TF) of Hg Compounds in Gypsum from Wet Flue Gas Desulfurization System of the Coal Fired Thermal Power Plant (TPP). American Journal of Analytical Chemistry, 6, 939-956. https://doi.org/10.4236/ajac.2015.612090

[56] Sui, Z., Zhang, Y., Li, W., Orndorff, W., Cao, Y. and Pan, W.-P. (2015) Partitioning Effect of Mercury Content and Speciation in Gypsum Slurry as a Function of Time. Journal of Thermal Analysis and Calorimetry, 119, 1611-1618. https://doi.org/10.1007/s10973-015-4403-9

[57] Lee, J.-Y., Cho, K., Cheng, L., Keener, T.C., Jegadeesan, G. and Al-Abed, S.R. (2009) Investigation of a Mercury Speciation Technique for Flue Gas Desulfurization Materials. Journal of the Air \& Waste Management Association, 59, 972-979. https://doi.org/10.3155/1047-3289.59.8.972

[58] Pavlin, M., Popović, A., Jaćimović, R. and Horvat, M. (2018) Mercury Fractionation in Gypsum Using Temperature Desorption and Mass Spectrometric Detection. Open Chemistry, 16, 544-555. https://doi.org/10.1515/chem-2018-0046

[59] Khan, M.A.K. and Wang, F. (2009) Mercury-Selenium Compounds and Their Toxicological Significance: Toward a Molecular Understanding of the Mercury-Selenium Antagonism. Environmental Toxicology and Chemistry/SETAC, 28, 1567-1577. https://doi.org/10.1897/08-375.1

[60] Córdoba, P. (2017) Partitioning and Speciation of Selenium in Wet Limestone Flue Gas Desulphurisation Systems: A Review. Fuel, 202, 184-195. https://doi.org/10.1016/j.fuel.2017.04.015

[61] Shah, P., Strezov, V., Prince, K. and Nelson, P.F. (2008) Speciation of As, Cr, Se and Hg under Coal Fired Power Station Conditions. Fuel, 87, 1859-1869.

https://doi.org/10.1016/j.fuel.2007.12.001 